\title{
Analysis of Notary Immunity Laws that Open Confidentials in Trial Based on Act No. 2 of 2014 Concerning Amendment to Act No. 30 Of 2004 Concerning Notary Office (Case Study Decision Number 83 / PID.B / 2011 / PN. SKA)
}

\author{
Mahfud Baihaqi *) \\ ${ }^{*}$ Students of Master of Notary Law, Universitas Islam Sultan Agung (UNISSULA) \\ Semarang
}

\begin{abstract}
As a legal instrument, on the one hand the notary has the right to refuse as a professional public official, by having to hold his oath of office not to disclose the contents of the act, on the other hand the notary must stand in the state's interest which refers to the public interest for the settlement process law in Justice, if in the investigation stage up to the hearing of a notary, it is necessary to become a witness in a criminal case, so as to produce a fair decision, useful and guarantee legal certainty. Purpose of research this To Know the Limits of Opening Secrets in a Court based on Invite Number2 of 2014 concerning Amendments to Act No. 30 of 2004 concerning the Position of Notary Public and To Know the Legal Consequences for Notaries who disclose secrets in court based on Invite Number2 of 2014 concerning Amendments to Act No. 30 of 2004 concerning the Position of Notary Public. The method used in this research is sociological juridical method, the specification in this research is descriptive analysis, the data used are primary data and secondary data, using data collection by interview and literature study, qualitative data analysis, problems analyzed by theory, law enforcement. And legal certainty. The results of this study indicate that In determining the extent to which the right of denial of the notary public must start from the obligation for the notary not to talk about the contents of his deeds, in the sense of either what is stated in his deeds or about what was notified or conveyed to him in his position as a notary. , even before a court of law, except for matters where there is a higher interest or in matters for which a notary by the applicable laws and regulations expressly exempt him from his oath of secret office. For the purposes of summoning a notary based on Article 66 paragraph 1 letter $b$. Police, prosecutors and judges must obtain prior permission from the Regional Supervisory Council. On the basis of the request for permission from the Police, the Regional Supervisory Council (MPD) shall hold a panel meeting to examine the notary regarding whether or not the notary is required to provide information at the examination of a criminal case.
\end{abstract}

Keywords: Notary Immunity; Secret of Position of Notary; Opening Secret Deed. 


\section{Introduction}

The essence of the State is a legal order or community order which has a coercive nature. ${ }^{1}$ Therefore, a legal order is incarnated in the form of legal regulations which, if not obeyed, will result in certain legal consequences in the form of sanctions. Law has many components or elements such as legal philosophy, legal sources, legal principles, statutory regulations, jurisprudence, customary law, law enforcement, legal services, the legal profession, legal institutions and institutions, legal profession behavior, legal awareness and so on. Which element is considered the most important depends on the philosophy of law adopted by the legal system in question. ${ }^{2}$ Law functions as a means of community renewal and protection of society so that laws need to be developed in a planned manner so that law as a means of community renewal can run harmoniously, in balance, in harmony, and in turn legal life reflects justice, social benefits and legal certainty. ${ }^{3}$

In line with legal developments and public needs regarding notary service users, Law of the Republic of Indonesia Number 2 of 2014 has been amended to Act No. 30 of 2004 concerning the Position of Notary Public. This Notary Position Law was promulgated with the intention of replacing the Reglement of Het Notary Ambt in Indonesie (Stb.1860 No.3, here in after referred to as PJPN-S. 1860 No.3) regarding the Notary Position Regulation which is no longer in accordance with legal developments and needs. Public. Until now, the notary position as a functionary in society is still respected. With the enactment of Act No. 2 of 2014 concerning the Position of Notary Public, is expected to provide legal protection both to the public and to the notary itself. A notary as an official, it is a place where someone can get reliable advice. Everything that he writes and determines (constants) is true, he is a strong document maker in a legal process. ${ }^{4}$ Notary, is a position of trust, so that someone is willing to entrust something to the notary.

The importance of the notary's role in helping to create legal certainty and protection for the community, is more preventive in nature, or has the character of preventing legal problems from occurring, by issuing authentic deeds made before them related to legal status, rights and obligations of a person in law, and so on, which functions as the most perfect evidence in court in the event of a dispute over related rights and obligations. ${ }^{5}$ According to law, a deed made by or

\footnotetext{
${ }^{1}$ Soehino. (1993). ILmu Negara. Yogyakarta : Liberty. p.191.

${ }^{2}$ Hartono, Sunaryati . (1991). Politik Hukum Menuju Satu System Hukum Nasional. Bandung : Alumni. p.38.

3 Tedjosaputro, Liliana. (1994). Etika Profesi Notaris Dalam penegakan Hukum Pidana. Yogyakarta : Biagraf Publishing. p.4.

${ }^{4}$ Kie, Tan Thong . (2000). Buku I Studi Notariat Serba-Serbi Praktek Notaris. cet. 2. Jakarta: PT. Ichtiar Baru Van Hoeve. p.157.

5 Adjie, Sjaifurrachman and Habib. (2011). Aspek Pertanggungjawaban Notaris dalam Pembuatan Akta. Bandung : CV. Mandar Maju. p. 7.
} 
before a notary is an authentic deed, whoever denies the truth of an authentic deed, the one who denies it must be able to prove otherwise. ${ }^{6}$

Authentic deeds as perfect evidence have an important role in every legal relationship in people's lives through authentic deeds that guarantee legal certainty, and at the same time it is hoped that disputes can be avoided even though disputes are not always avoided. In the dispute resolution process, the authentic deed which is the strongest and most fulfilled written evidence gives a real contribution to the settlement of the case. According to the definition contained in Article 1 paragraph (1) of Act no. 2 of 2014 concerning the Position of Notary, namely: Notary is a public official who is authorized to make authentic deeds and other powers as referred to in this Law. Other powers referred to in the Law relating to authentic deeds, namely in Article 15 paragraph (1) of the Law on Notary Position,

"Notaries have the authority to make authentic deeds regarding all deeds, agreements, and provisions required by the laws and regulations and / or those interested in being stated in the authentic deed, guarantee the certainty of the date of making the deed, keep the deed, provide grosse, copies and quotations. The deeds, all of that as long as the making of the deeds are also assigned or exempted to other officials stipulated by the law. "

The aim is that the deed can be used as strong evidence, if at any time there is a dispute between the parties or there is a lawsuit from another party. If this happens, it is possible that the notary will be involved in the matter. In addition to making authentic deeds, notaries are also obliged directly or indirectly to maintain the smooth running of the legal process that occurs, including with regard to judicial processes, both in criminal and civil proceedings. The judicial process referred to here is closely related to evidence, both evidence in writing (written evidence) and evidence by testimony (witnesses). In the criminal justice process, there is a process of evidence that emphasizes evidence according to Article 184 paragraph (1) of the Criminal Procedure Code (KUHAP):
a. witness testimony;
b. expert statement;
c. letter;
d. instructions;
e. statement of the defendant.

Article 1866 Civil Code which can be used as evidence, namely:
a. written evidence;
b. evidence with witnesses;
c. prejudice;
d. recognition;
e. oath;
f. all things with regard to the rules laid down in the next chapter.

${ }^{6}$ Kohar, A. (1983). Notaris Dalam Praktek Hukum. Bandung: Alumni. p.28. 
As for what is meant by authentic deed according to Article 1868 of the Civil Code, namely a deed which is in the form stipulated by law, is made by or in front of a public employee who has power to do so, at the place where the deed was made. Authentic deeds have three types of strength, namely: ${ }^{7}$

a. The strength of external proof, namely the ability of the deed itself to prove itself to be an authentic deed.

b. The strength of formal proof, namely insofar as the official deed, the deed proves the truth of what is witnessed, namely what is seen, heard and also done by the notary as a public official in carrying out his obligations.

c. The strength of material proof, namely proving that the contents of the information contained in the deed are true.

As the cases go from time to time, and the cases that occur are alternating, in certain cases the litigating parties (can be represented by lawyers), prosecutors, judges, or other parties concerned in court who feel the need to present a notary as a witnesses, related to the deed he made. The existence of a notary as a witness, if it is related to the existence of his position in the legal field, is obliged to support the smooth running of the judicial process, does not appear to be a problem. In other words, it is only natural for a notary to act as a witness in a judicial process. In the event of a dispute, the authentic deed which is the strongest and most fulfilled evidence can make a real contribution to the settlement of the case cheaply and quickly. ${ }^{8}$

The follow-up to the duties carried out by the notary has a legal impact, meaning that every notary deed can be used as a means of proof, if there is a dispute between the parties, the dispute does not rule out involving a notary public, and for that involvement the notary must be responsible for what he has done. The judge has full authority and decides on the existence of a dispute, and for that the judge has the right to judge what and how the disputed deed is. ${ }^{9}$ Notaries can be held accountable other than under the provisions of Act No. 2 of 2014 concerning the Position of Notary Public, also based on the Notary Code of Ethics. According to Article 4 paragraph (1), namely: before a notary performs his position, he must first take an oath / promise according to his religion before the Minister or appointed official. Among other things, the oath reads as stated in Article 4 paragraph (2), namely:

I swear / promise:

That I will obey and be loyal to the Republic of Indonesia, Pancasila and the 1945 Constitution of the Republic of Indonesia, the Law on the Position of Notary

\footnotetext{
${ }^{7}$ Tobing, G.H.S. (1996). Lumban . Peraturan Jabatan Notaris, Jakarta: Erlangga. p. 55.

${ }^{8}$ Peraturan Menteri Hukum dan HAM RI. (2004). "Pelaksanaan Tugas Majelis Pengawas Notaris dan Tata Cara Pengangkatan Anggota, Pemberhentian Anggota, Susunan Organisasi, Tata Kerja dan Tata Cara Pemeriksaan Majelis Pengawas Notaris". Jakarta : Dep. Hukum and HAM RI.

${ }^{9}$ Kohar, A. loc.cit. p. 28.
} 
Public and other laws and regulations. That I will carry out my position with trust, honesty, thoroughness, independence, and impartiality. That I will maintain my attitude, behavior, and will carry out my obligations in accordance with the Professional Code of Ethics, honor and dignity, and my responsibilities as a notary. That I will keep secret the contents of the deed and the information obtained in the exercise of my position. That I have never been and will not give or promise anything to anyone, either directly, under whatever name or pretext.

Article 16 paragraph (1) letter f, in carrying out his / her position, a notary is obliged to:

"Keep everything about the deed made and all information obtained in order to make the deed in accordance with the oath / promise of office, unless the law stipulates otherwise."

Article 54, states that:

"Notaries can only give, show, or notify the contents of the deed, grosse deed, copy of deed or excerpt of deed to people with direct interest in the deed, heirs, or people who obtain rights, unless otherwise stipulated by legislation."

The notary's obligation to keep everything connected with the deed and other documents as regulated in the UUJN above is to protect the interests of all parties related to the deed. The position of notary as a position of trust automatically creates an obligation to maintain the confidentiality of everything entrusted to him. This obligation will end if there is an obligation according to law to speak, that is, when someone is summoned as a witness. ${ }^{10}$

In the Criminal Procedure Code, Civil Law, and Criminal Law are regulated in Article 170 paragraph (1) of the Criminal Procedure Code, Article 1909 of the Civil Code, and Article 322 paragraph (1), each of which reads:

Article 170 paragraph (1) KUHAP:

"Those who because of their job, dignity, or position are obliged to keep secrets, can ask to be exempted from the obligation to testify as witnesses, namely about the things entrusted to them."

Article 1909 paragraph (2) letter 3e of the Civil Code:

"Anyone who because of their position, job or his position according to the Law, is obliged to keep something secret, but only on matters whose knowledge is entrusted to him as such. "

Article 322 paragraph (1) of the Criminal Code:

"Anyone who deliberately discloses a secret which is obliged to be kept because of his current or former position or search, is punishable by a maximum imprisonment of 9 (nine) months or a maximum fine of IDR 600, - (six hundred). "

${ }^{10}$ Tobing, Lumban . (1993). Peraturan Jabatan Notaris, Jakarta : Erlangga. p. 13. 
Notary according to legal provisions, must not take sides, meaning that in assisting the parties to formulate a deed, they must pay attention to the interests of both parties and must keep secret in relation to the contents of the deed they write. Especially if there is a dispute between the two parties, which results in an investigation of the notary deed. The purpose of the investigation is to find and collect evidence. ${ }^{11} \mathrm{~A}$ notary is obliged to keep secret the contents of the deed, not only what is stated in the deeds, but also everything that is notified or conveyed to him in his capacity as a notary, even though this is not included in the deeds.

As a legal instrument, on the one hand the notary has the right to refuse as a professional public official, by having to hold his oath of office not to disclose the contents of the act, on the other hand the notary must stand in the state's interest which refers to the public interest for the settlement. Process law in judiciary, so as to produce a fair decision, useful and guarantee legal certainty. With a mandate given to a notary public, the notary's responsibility for a deed does not only concern personal interests, but also concerns the public interest. As stipulated in the last sentence of Article 16 paragraph (1) letter $f$ of the Law on Notary Position, namely: "unless the Law stipulates otherwise", and the last sentence as stated in Article 54, namely: "unless otherwise stipulated by statutory regulations". In both articles, it seems that a Notary Public can inform the contents of the deed to parties who do not have a direct interest in the deed he makes, as long as it is supported by laws and regulations.

Since the enactment of Act No. 2 of 2014 amendments to Act No. 30 of 2004 concerning the Position of Notary Public, the District Court is not authorized to supervise notaries, this supervision is carried out by the Minister of Law and Human Rights as stipulated in Article 67 of the UUJN, which states that Supervision of notaries is carried out by the Minister, then in the next paragraph to carry out supervision, the Minister forms a Supervisory Council consisting of elements from the government, notary organizations and academics.

The Notary Supervisory Council, as the spearhead of supervision, should not be filled by a person who does not master notary, based on the provisions stipulated in Article 66 paragraph (1) letters a and b of the Law on Notary Position, states that:

"For the purposes of the judicial process, investigators, public prosecutors, or judges with the approval of the Notary Honorary Council are authorized to:

a. Take a photocopy of the Minuta Deed and / or letters attached to the Minuta Deed or Notary Protocol in the notary's deposit; and

b. Calling the Notary Public to be present in the examination relating to the deed he has made or the Notary Protocol that is in the Notary's deposit ".

${ }^{11}$ Prodjohamidjojo, Martiman. (1985). Penyelidikan dan Penyidikan. Jakarta: Ganesa Indonesia. p. 26. 
With the aforementioned provisions, for the purpose of investigation, the Notary Honorary Council must obtain approval. The formation of the Notary Honorary Council, including the procedures, how to conduct the examination then how the procedure is regulated in the Regulation of the Minister of Law and Human Rights of the Republic of Indonesia Number 7 of 2016. In following up on reports of people who feel aggrieved for making deeds, then submit a report to the Notary Honor Council, If there are violations that have occurred, then the sanctions have been regulated, in the form of verbal, written warning, temporary or permanent dismissal.

This shows the existence of confidentiality and that it is not easy to take a photocopy of the Minuta Deed and / or the letters that are attached to the Minuta Deed or Notary Protocol in the Notary's deposit and call the Notary to be present at the examination, relating to the deed he made on the Notary Protocol which is in the notary's storage. The Notary Honorary Council, must also hear the statement of the notary who made a deed which is used as evidence. The notary's obligation to keep secret the contents of the deed he makes regarding all matters that is notified or entrusted to him, in the framework of carrying out his office, the notary must keep secret as much as possible in accordance with his oath of office.

Supervision is a preventive and repressive activity carried out by the Minister of Law and Human Rights, the implementation of which is carried out by establishing a Supervisory Council, which aims to ensure that Notaries in carrying out their profession do not neglect their duties, do not violate applicable regulations, do not violate oaths. his position, and does not violate the Code of Ethics of his profession, apart from that by providing prosecution for violations committed by a Notary. To get a higher quality notary performance, prior supervision is needed. The Supervisory Council, as the spearhead of supervision, is expected to be useful to supervise every implementation of the position and behavior of a Notary in the form of effective protection and guidance as it should be. ${ }^{12}$

Given the complexity of the duties and obligations of a Notary Public in modern life, as well as considering the characteristics of his duties, Notaries who carry out their duties in good faith need to obtain juridical protection, such as the benefits of having a supervisory institution as referred to in Act No. 2 of 2014 amendments to Act No. 30 of 2004 concerning the Position of Notary. In this case, it is desirable to have a standard legal protection standard. The government cares for and trusts the world of academia as a control over the implementation of office and behavior of notaries.

A series of innovations in the Notary Position Law that is faced with the previous regulations, is a reform, it requires reasonable attention from further thought, for example Government Regulations, Ministerial Regulations, Joint Decrees, or

12 Majelis Pengawas Pusat Notaris Departemen Hukum and HAM Republik Indonesia, "Pemberian atau Penolakan Persetujuan Pemanggilan Notaris". Renvoi. Oktober 2005. p. 63. 
Circular Letters and others. With the existence of a supervisory agency as referred to in the Law on the Position of Notary Public, and ideally the implementation of the Position of Notary Public can be carried out in a trustworthy, honest, thorough, independent, impartial, and can carry out his position professionally. Thus, in the end it can serve and help the community whole hartedly and support just legal certainty.

Based on the description of the background, the authors are interested in researching and reviewing the implementation of the Immunity of Notary Office which discloses secrets in the trial, for that the author will take the title of the thesis, namely NOTARY IMMUNITY LEGAL ANALYSIS THAT OPENS SECRETS IN TRIALS BASED ON Invite Number 2 of 2014 concerning Amendments to Act No. 30 of 2004 concerning the Position of Notary Public.

\section{Research Methods}

The approach method used in this study is a sociological juridical approach. The sociological juridical approach is an approach based on the main legal materials by examining theories, concepts, legal principles and laws and regulations related to this research.

\section{Results and Discussion}

3.1. Limitation on Disclosure at Court based on Act No. 2 of 2014 concerning Amendments to Act No. 30 of 2004 concerning the Position of Notary Public In the position of a notary as a witness (civil case), the notary can ask to be exempted from the obligation to testify because his position according to the law is obliged to keep his position confidential. In accordance with Article 1909 paragraph (3) of the Civil Code. In this case, the notary has the obligation to refuse not for the notary's self interest but for the interests of the parties who have entrusted the making of the Deed to the notary. Article 54 of the Law on Notary Office reads "Notaries can only provide, show or notify the contents of the deed, Grosse Deed, Copy of Deed and Quotation of Deed to people with direct interest in the deed, heirs or people who have rights, unless otherwise stipulated by statutory regulations." From this article, it is clear that the notary has instructed him not to give, show or notify contents of the deed except to those with direct interest. For example, when the parties related to the deed have a dispute and there are other parties who want to get news and then meet the notary who made the deed, the notary must use his memory rights in order to protect the interests of the parties.

In determining the extent to which the right of denial of the notary public must start from the obligation for the notary not to talk about the contents of his deeds, in the sense of either what is stated in his deeds or about what was notified or conveyed to him in his position as a notary. Even before a court of 
law, except for matters where there is a higher interest or in matters for which a notary by the applicable laws and regulations expressly exempt him from his oath of secret office.

In carrying out their duties, the notary has a number of powers that he does. The definition of authority is the right and power that is owned to do something. In relation to the authority possessed by a notary, the notary is a public official authorized to make an authentic deed. This is based on the provisions of Article 1868 of the Civil Code which states that: An authentic deed is a deed which is in the form prescribed by law, made by or in front of public officials who are in power for it at the place where the deed was made. As an implementation and elaboration of Article 1868 of the Civil Code, it must first determine what is meant by the said public official. Based on Article 1 of the Law on Notary Position, the official is a notary.

The authority of a Notary based on the provisions of Article 15 paragraph (1) of the Law on Notary Position, namely: Notary is authorized to make authentic deeds regarding all actions, agreements and decisions required by laws and regulations and / or which is desired by those concerned to be stated in the authentic deed, guarantees the certainty of the date of making the deed, keeps the deed, provides grosse, copies and excerpts of the deed, all of which as long as the making of the deeds is not assigned or excluded to other officials or other people determined by Constitution.

Regarding the authority of a notary as a public official, there are the following elements:

a. "General Officer", does not mean that the notary is a civil servant as referred to in Act No. 8 of 1974 concerning Personnel Principles, but the position referred to in Article 1868 of the Civil Code. Although notaries are appointed and dismissed by the government, they do not receive a salary, retire from the government. Notary position is not a position that is paid for, notary does not receive a salary from the government, instead, they get an honorarium from those who ask for the services of a notary.

b. "Authentic Deed", according to Article 1868 of the Civil Code, is a deed which in the form according to the provisions of the Law is made by or before a public official who has the authority to do so at the place where the deed was made.

c. "All acts of agreement and determination required by a general regulation or desired by those concerned", can be interpreted that the deeds made by or before a notary are limited to deeds concerning civil law and what the interested party wants. and based on Law (legal regulations).

d. "Guarantee the certainty of the date", it should be defined as the date the deed was drawn up and signed according to reality. 
e. "Keeping the deed", which requires notaries to keep Minuta Deed, Repertorium, Book of Deeds under hand, Clipper, Protest List Book, Will List Book, other register books that must be kept by the notary. And must keep it carefully or carefully in a proper and safe place.

f. "Grosse Deed", has the same executorial power as that given to the judge's decision (verdict) which at the top reads "DEMOCRACY BASED ON ONE ALMIGHTY GOD".

In principle, the authority granted to a notary is general authority. General authority means that this authority includes the making of all types of deeds, except those that are not made by a notary public. This saying also implies that other officials, apart from notaries, only have certain deed authority and must be based on the statutory regulations governing it. In carrying out his duties as a public official, he must be impartial, in accordance with the contents of his oath of office, which determines that the notary will carry out his / her duties in a trustworthy, honest, thorough, independent, and impartial manner.

Obligations of Notaries as General Officials. The essence of the notary's duties as an official general is to record in writing and authentically the legal relationships between the parties, who have agreed to request the assistance of a notary. As far as possible, the notary must try to know that the identity and statements of the parties are the truth. The notary can obtain these information from people he knows and trusts or can see proof of identity from the parties. However, if it turns out that all information given by the parties is untrue, then all of that is not the responsibility of the notary, because the notary is only responsible for the formal truth that the parties have given. Based on this, the notary's accountability for the deeds he makes must be supported by an accountable moral will.

In court proceedings, judges really need a basis for evidence to be able to reach a verdict and resolve the case with certainty according to law based on the evidence submitted. With proof, it is hoped that the truth can be reached according to the law and can guarantee the protection of the rights of the parties in litigation, in a balanced manner.

An event that gives rise to a right must be proven by the party claiming that right, while an event which removes the right must be proven by the party denying it. By itself, if there is no evidence submitted or insufficient evidence is presented in court, then the right claim or lawsuit will be rejected or not granted. So, the role of the notary in this case is to provide services to the public, to create authentic evidence that has perfect evidentiary power, to free or awaken members of the public from fraud or bad faith from certain people and to guarantee the rights and obligations of parties who have an interest in it. Thus, between notaries and parties who need notary services must have integrity, In a civil case process, one of the duties of a judge is to investigate whether a legal relationship on which the lawsuit is based actually exists or not. The existence of this legal relationship must be proven if the plaintiff wants victory in 
a case. If the plaintiff fails to prove his arguments on which his lawsuit is based, he will be rejected, whereas if, successful, his claim will be granted. Proof of an event, regarding the existence of a holden relationship is a way to convince the judge of the truth of the arguments on which the lawsuit is based, or the arguments that have been put forward by the opposing party. In impose the burden of proof, judges must act wisely and wisely, and must be fair and impartial.

After the enactment of Act No.30 of 2004 concerning the Position of Notary Public, in the oath of Notary Public it states that, the notary promises under oath to keep the deeds and information obtained secret. Article 16 paragraph (1) letter e, also states that in In carrying out his office, a notary is obliged to keep secret everything concerning the deed he has drawn and all information he has obtained for making the deed in accordance with the statement of oath / promise of office, unless the law stipulates otherwise The Oath of Position of Notary in Article 4 and the obligations of a notary in Article 16 paragraph (1) letter e The Law on Notary Position, requires notaries not to speak, even in court, meaning that they are not allowed to give testimony regarding what is contained in the act. The notary is not only entitled to speak, but has the obligation not to speak. This obligation overrides the general obligation to testify as referred to in Article 1909 of the Civil Code. Notary is a position of trust, and for the benefit of society, and therefore a person willing to entrust something to him. As an entrusted person, the notary is obliged to keep secret everything that is notified to him in his position as a notary, even if some parts are not included in the deed.

Article 322 paragraph (1) of the Criminal Code states: Anyone who deliberately with secret which he is obliged to keep because of his position or occupation, both present and past, shall be punished with imprisonment of up to 9 (nine) months or a fine, amounting to IDR 600, - (six hundred rupiah).

A notary deed that is questioned before a court hearing in a civil case with a deed made by a notary, it is more appropriate to present a notary who made the deed as an expert witness. The presence of a notary who makes a deed which is used as evidence in a case is not as an ordinary witness but as an expert witness who will explain what the witness knows according to the witness's expertise, related to the standard procedure for the issuance of a notary deed.

According to laws and regulations, expert witnesses are known as expert statements. In accordance with Article 186 of the Criminal Procedure Code which states that expert testimony is what an expert states in a court session. The elucidation of this article explains that this expert's statement can be given during examination by an investigator or public prosecutor which is written in a report and made by binding an oath when a notary accepts a position or job. Any person according to the criminal procedural law can be appointed as an expert witness, namely having knowledge and experience of the matter. A notary is an official who is authorized according to the provisions of laws and regulations to 
make a deed that records everything that is witnessed and requested to be published in it by the parties concerned, so that the notary's testimony about what was seen and what was witnessed by the notary was stated in act. So a notary actually no longer needs to be summoned as a witness in a trial to explain what was witnessed and what was conveyed to him at the time the deed was drawn up.

A notary who is used as a witness in a case must obtain approval from the Regional Supervisory Council. As it is known, notaries are supervised by the Notary Supervisory Council. In Article 66 paragraph (1) of the Law on the Position of Notary Public, it states that in the interests of the judicial process, investigators, public prosecutors and judges with the approval of the Regional Supervisory Council are authorized:

1) Take a photocopy of the Minuta Deed and / or Letters attached to the Minuta Deed, or Notary Protocol in the notary's deposit;

2) Calling the notary public to attend the examination related to the deed he made or the Notary Protocol that is in the notary's deposit.

In connection with the summoning of a notary as a witness before the court in both civil and criminal cases, especially in relation to the deed he makes, can the notary in this case demand the enactment of the provisions referred to in Article 50 of the Criminal Code, which stipulates that whoever commits an act to implement the provisions Law, not convicted. The point is anyone who because of carrying out a statutory regulation cannot or cannot be punished. These problems depend on whether the right to deny him by law is only a right or only an obligation and whether in this case there is a higher interest or not. In this regard, there are three obligations for someone who is summoned as a witness, among others:

1) The obligation to appear, means that if someone is called as a witness then they must accept and fulfill the summons as long as this is not an exception and even if they refuse without a valid reason according to law, then they may be subject to sanctions.

2) Obligation to take an oath, meaning that basically everyone before giving a statement before the court must be sworn in first.

3) Obligation to provide information. So, if the right to refuse is only a right, then a notary may demand that the provisions referred to in the Article be enforced. 50 of the Criminal Code. However, because the right of refusal granted by law to a notary is an obligation and based on the secret oath of office as stated in Article 4, as well as the provisions contained in Article 54 of the Law on the Position of Notary Public, there is no obligation for a notary to testify even in court. Thus, the enforcement of Article 50 of the Criminal Code does not have a strong legal basis, except in the case of a higher interest. 


\subsection{Legal consequences for notaries who disclose secrets in court based on Invite Number2 of 2014 concerning Amendments to Act No. 30 of 2004 concerning the Position of Notary Public}

If a notary discloses the secret of the position that has been entrusted to him, then he or she will be subject to punishment under Article 322 of the Criminal Code. From the explanation above, it can be concluded that a notary public must defend the right of denial to maintain the confidentiality of the deed he makes as long as it is not related to the parties concerned or because the law determines otherwise, such as when a notary is asked to be a witness before the court.

If the Notary or notary employee leaks the contents of the Deed to other people who have no interest and causes harm to the parties concerned, then the notary can be sued according to Article 1365 of the Civil Code which states that every act violates the law, which brings harm to others, obliging the person who due to his fault published the loss, compensate the loss.

Violation of the obligation to maintain confidentiality of office may result in a notary being subject to sanctions by the Notary Supervisory Council, this is in accordance with the provisions of Article 85 of the Law on Notary Office, among others: verbal warning, written warning, temporary dismissal, respectful dismissal, dishonorable discharge by the Minister. Upon the proposal of the Central Supervisory Council.

Legal protection for Notaries is intended, so that the rights and authorities as well as the obligations of Notaries in carrying out their duties as provided by UUJN and the Code of Ethics are carried out based on applicable provisions, both based on law and based on moral and professional ethics, for the sake of ensuring legal protection and legal certainty for the profession. Notary and public interest.

This will create a sense of calm, peace and guaranteed legal protection for Notaries in carrying out their duties as General Officials. The notary will feel protected because all examination actions are carried out after careful examination and examination by the Supervisory Board as regulated in Article 66 of the UUJN, but the Supervisory Council cannot provide any protection to Notaries who are found guilty of carrying out the position of Notary.

The scope of the implementation of the notary's duties, namely within the scope of the law of proof, this is the duty and authority of the notary, namely to make the evidence desired by the parties in the case of certain legal actions. The existence of such evidence is within the scope or level of civil law. Because the work of the notary to make the deed at the request of the tappers, without a request from the tappers, the notary will not make anything. The notary makes a deed based on evidence or statement / statement of the parties which is stated or explained or shown to or in front of the notary, and then the notary frames it physically, formally and materially in the form of a notary deed,

The role of the notary in this case is also to provide legal advice in accordance with the existing problems as required by article 15 paragraph (2) letter e. UUJN. 
Whatever legal advice is given to the parties and then poured into the deed concerned, it remains as the wish or statement of the parties concerned, not and not as a statement or statement of a notary public. In notary practice, it is found that if there is a notary deed disputed by the parties or other parties, then the notary is often with drawn as the party who participated in or helped commit a criminal act, namely making or providing false information on the notary deed. In this connection, this does not mean that the notary is sterile or clean from the law or cannot be punished or immune to the law. A notary can be sentenced to a criminal sentence if it can be proven in court that the notary intentionally or unintentionally worked together with the parties / parties to make a deed with the intent and purpose of benefiting certain parties or parties or harming other parties If this is proven in court, the notary must be punished. Therefore, only notaries who are insane in carrying out their job duties, when making deeds for the benefit of certain parties with the intention of harming certain parties or to commit an act that violates the law.

In the framework of the evidentiary process of the indication of a criminal act in the authentic deed mentioned above, it is necessary to have the presence of a notary in criminal case examination starting from the level of investigation at the Police, prosecution by the Prosecutor's Office to the proving process at trial at court. The need for the presence of a notary in the examination of criminal cases related to deeds made and indicated by a criminal act is largely determined by the formal and material aspects of the notary deed itself. In cases that often involve a notary as a suspect based on preliminary evidence in a police report related to a notary deed he has made it is deemed to indicate a criminal act, so the notary needs to be summoned to explain the process of the deed, and the evidence base on which the deed is made. For the purposes of summoning a notary based on Article 66 paragraph 1 letter $b$. The police must first obtain permission from the Regional Supervisory Council. On the basis of the request for permission from the Police, the Regional Supervisory Council (MPD) shall hold a panel meeting to examine the notary regarding whether or not the notary is required to provide information on criminal case examination at the Police as stated in the application letter for notary examination permit received by the Regional Supervisory Council. Based on the results of the session of the supervisory panel, the Regional Supervisory Council gave permission to carry out an investigation or request information from the notary.

The provisions of Article 66 of the UUJN are imperative or mandatory, meaning that if the Police, Attorney General's Office or Judges underestimate the provisions of Article 66 of the UUJN, then the Police, Attorney's Office or Judges can be categorized as violations of the law, so if this happens, we can report the Police, Attorney General's Office. and Judges to their respective superiors, and on the other hand, a case that is investigated or examined can be categorized as a legal subject (in terms of Criminal Procedure Law) which cannot be continued (temporarily suspended) until the provisions of Article 66 of the UUJN are 
fulfilled. There are also Notaries who are summoned by the Police, Attorney General's Office or Judges who come directly to the agency that summoned them, without being examined first by the Regional Supervisory Council.

Although a notary has legal immunity given by law in the form of an obligation to refuse to give information regarding the secret of his position, and this immunity is manifested by the right to deny or resign as a witness as long as it is related to statements that are confidential in nature. As a public official who runs public services in the field of legal services, it is necessary to distinguish between errors that are personal (faute personelle or personal fault) and errors in carrying out their duties (faute de serive or in service fault).

1. Those who are because of work, dignity dignity or their position is obliged to keep a secret, may ask to be exempted from the obligation to give testimony as a witness, namely about the matter entrusted to them.

2. The judge determines whether or not the reasons for the request are valid.

Based on article 65 UUJN, notary public is responsible for any deeds he makes even though the notary protocol has been submitted to the notary protocol keeper. This means that the notary's responsibility does not end even though the notary has retired / retired, so that at any time he can be held accountable for the deed made. And based on Article 184 of the Criminal Procedure Code (KUHAP). In a criminal case, the evidence for witness testimony is the main evidence in addition to other evidence such as expert testimony, letters (written evidence), instructions and statements of the defendant. There is no criminal case that escapes the proof of evidence of witness testimony. Almost all proof of criminal cases always relies on examination of testimony. At least in addition to evidence with other evidence, such as presumption or written evidence, even a confession from the defendant, it is always necessary to prove it by means of evidence from witness testimony. Therefore, in order to obtain an objective and perfect examination result, the investigator is very demanding for the testimony of the witness, even though the witness is a notary.

It has become the basis of public law that a public official, before carrying out his position legally, must first take an oath (take the oath). As long as this has not been done, the position may not or cannot be carried out legally. In carrying out his / her duties, a notary must be based on the existing authority of the position. Notary himself.

In accordance with the contents of Article 4 paragraph (1) of the Law on the Position of Notary which states, prior to carrying out his office, a notary is obliged to take an oath / promise according to his religion before the Minister or a designated official. Whereas in paragraph (2) states: I swear / promise: That I will patch and be loyal to the Republic of Indonesia, Pancasila, and the 1945 Constitution of the Republic of Indonesia, the Law on the Position of Notary, as well as other laws and regulations. That I will carry out my position with trust, 
honesty, thoroughness, independence, and impartiality. That I will maintain my attitude, behavior, and will carry out my obligations in accordance with the Professional Code of Ethics, dignity, and my responsibilities as a notary. That I will keep secret the contents of the deed and the information obtained in the exercise of my position. That I have never been and will not give or promise anything to anyone, either directly, under whatever name or pretext. Based on the provisions set out in Article 4, it states that the notary who was appointed before taking the oath is not allowed to carry out a job that is included in the field of Notary Position. Before an oath of office is held for a notary, the notary is not entitled to make an authentic deed. If a notary violates these provisions, then in addition to being subject to sanctions, the deed made by the notary will not have an authentic character but only act as an underhand deed when signed by the parties. In his oath of office, the Notary states, the notary promises under oath to keep secret the contents of the deed and the information he has obtained. Article 16 paragraph (1) letter e also states that in carrying out his position, notaries are obliged to keep secret the deeds they have drawn and all information obtained for making deeds in accordance with the oath / promise of office, unless the law stipulates otherwise.

The elucidation of the Article states that the obligation to keep everything related to the deed and other documents is confidential is to protect the interests of all parties related to the deed. Article 322 paragraph (1) of the Criminal Code also states that anyone who deliberately discloses a secret that he is obliged to keep because of his position or occupation, both present and past, will be punished with imprisonment of up to 9 (nine) months or a fine of up to IDR 600, - (six hundred rupiah). Based on the two Articles that have been described above, it is clear that notaries must keep secret in relation to their position. Notaries are obliged to keep the contents of their deeds confidential, even a notary is obliged to keep all information confidential from the preparation of the deed to the completion of the deed. If they become witnesses in a case, they can exercise their right to resign as witnesses.

If a notary discloses the secret of the position assigned to him, then he or she will be punished under Article 322 of the Criminal Code:

a) Anyone who deliberately discloses a secret which is obliged to be kept by him because of his current or former position or search, shall be punished with a maximum imprisonment of 9 (nine) months or a maximum fine of IDR 600, (six hundred).

b) If a crime is committed against a certain person, then that act can only be prosecuted upon complaint by that person.

If due to the disclosure of someone's secret by a notary public or notary's employee, so that it becomes known to the public and results in losses for the person concerned, the notary can be sued on a civil basis based on: Article 1365 
The Civil Law states that every act of breaking the law, which brings harm to other people, obliges the person who due to his wrongdoing to issue the loss, to compensate the loss.

Keeping everything about the deed made and all information obtained in order to make the deed is one of the obligations of the notary public. Violation of the obligation to maintain confidentiality of office may result in a notary being subject to sanctions by the Notary Supervisory Council, this is in accordance with the provisions of Article 85 of the Law on Notary Position, among others:

1. Verbal warning;

2. Written warning;

3. Temporary suspension;

4. Honorific dismissal;

5. Disrespectful dismissal by the Minister at the suggestion of the Central Supervisory Council.

\section{Closing}

\subsection{Conclusion}

Limitation on Disclosure at Court based on Invite Number2 of 2014 concerning Amendments to Act No. 30 of 2004 concerning the Position of Notary Publicwhere the Notary is a public official and as a position of trust (vertronwens ambts) has an obligation to keep secret the contents of the deed made by and before him and all information given by the informers and Notaries so that the Notary is obliged to keep it a secret because it is bound by the oath / secret of office in Article 4 UUJN. However, if the deed made by or before a Notary Public has indications of a criminal act where the Notary must release or ignore the obligation to keep secrets related to the contents of the deed due to public or State interests and to assist the legal process. A notary is not allowed to secretly disclose the contents of the deed he has drawn as regulated in Article 16 paragraph (1) letter e of the Law on Notary Office which states that the Notary is obliged to keep secret the deed he has drawn and all information obtained for making deeds in accordance with the oath / promise of office, unless the law stipulates. On the basis of this, the Notary Public has the right of denial in order to protect the confidentiality of the deeds he has made. However, if the notary has been permitted by the Notary Honorary Council (MKN) to be present as a witness in criminal proceedings, the right of notary refusal will be annulled because of its existence. Higher legal interest. The right to refuse can only be used as long as there are no statutory provisions that can invalidate a notary's right to refuse. 


\subsection{Suggestion}

Notaries should better understand and optimize in providing information on the contents of deeds that they do regarding the secret of their position based on UUJN. So that in terms of providing information on deeds which he has done in the public interest and in the legal process, he must uphold the oath of office, secrecy of office and the right to refuse as an effort to enforce the law. Notaries should in facing criminal cases related to the contents of deeds that they do always adhere to professional ethics, oath of office, respect applicable legal provisions, know the limits of their authority and be accountable for the deeds they have done, as well as law enforcement officials both investigators, public prosecutors and judges understand rights and obligations of a Notary on the deed he has done.

\section{References}

Journals:

Pan Mohamad Faiz. (2009). "Teori Keadilan John Rawls" in Jurnal Konstitusi. Volume 6 No. 1.

Books:

[1] Kohar, A. (1983). Notaris Dalam Praktek Hukum. Bandung: Alumni.

[2] Wijaya, Andika. (2017). Penanganan Perkara Kepailitan Dan Perkara Penundaan Pembayaran Secara Perxis. Bandung: Citra Aditya Bakti.

[3] Friedrich, Carl Joachim. (2004). "Filsafat Hukum Perspektif Historis. Bandung: Nuansa dan Nusamedia.

[4] Manullang, E Fernando M. (2007). Menggapai Hukum Berkeadilan (Tinjauan Hukum Kodrat Dan Antinomi Nilai). Jakarta: PT. Kompas.

[5] Tobing, G.H.S. Lumban. (1996). Peraturan Jabatan Notaris. Jakarta. Erlangga. 
[6] Adjie, Habib. (2013). Kebatalan dan Pembatalan Akta Notaris. Bandung: Refika Aditama.

[7] Kelsen, Hans. (2011). "General Theory of Law and State". Diterjemahkan oleh Rasisul Muttaqien. Bandung: Nusa Media.

[8] Rawls, John. (2006). "A Theory of Justice. London: Oxford University press". yang sudah diterjemahkan dalam bahasa indonesia oleh Uzair Fauzan dan

[9] Heru Prasetyo. Teori Keadilan. . Yogyakarta : Pustaka Pelajar

[10] Masyhur, Kahar. (1985). "Membina Moral dan Akhlak". Jakarta: Kalam Mulia.

[11] Apeldoorn, L. J. Van. (1996). "Pengantar Ilmu Hukum". Cetakan kedua puluh enam Pradnya Jakarta: Paramita.

[12] Tedjosaputro, Liliana. (1994). Etika Profesi Notaris Dalam penegakan Hukum Pidana. Yogyakarta: Biagraf Publishing.

[13] Tobing, Lumban. (1993). Peraturan Jabatan Notaris. Jakarta: Erlangga.

[14] Prodjohamidjojo, Martiman. (1985). Penyelidikan dan Penyidikan. Jakarta: Ganesa Indonesia.

[15] Rahardjo, Satjipto. (1983). Masalah Penegakan Hukum. Suatu Tinjauan Sosiologis. Bandung: Sinar Baru. 
[16] Adjie, Sjaifurrachman and Habib. (2011). Aspek Pertanggungjawaban Notaris dalam Pembuatan Akta. Bandung: CV. Mandar Maju.

[17] Dirdjosisworo, Soedjono. (2001). Pengantar Ilmu Hukum. Jakarta: Radja Grafindo Persada.

[18] Soehino. (1993). ILmu Negara. Yogyakaerta: Libery.

[19] Soekamto, Soejono. (1986). Pengantar Penelitian Hukum. Jakarta: UI Press.

[20] and Sri Mamudi. (1995). Penelitian Hukum Normatif Suatu Tinjauan Singkat. Jakarta: PT.Raja Grafindo Persada.

[21] (2003). Pokok-Pokok Sosiologi Hukum. Jakarta: Radja Grafindo Persada.

[22] Sudarsono. (2002). Kamus Hukum. Edisi Baru. Cetakan ketiga. Jakarta: Rineka Pers.

[23] Lunis, Suhrawardi K. (2000). "Etika Profesi Hukum". Cetakan Kedua. Jakarta: Sinar Grafika.

[24] Suryabrata, Sumadi. (1998). Metodologi Penelitian. Jakarta: Raja Gofindo.

[25] Hartono, Sunaryati. (1991). Politik Hukum Menuju Satu System Hukum Nasional. Bandung: Alumni. 
[26] Kie, Tan Thong. (2000). Buku I Studi Notariat Serba-Serbi Praktek Notaris. cet. 2. Jakarta: PT. Ichtiar Baru Van Hoeve.

[27] Majelis Pengawas Pusat Notaris Departemen Hukum dan HAM Republik Indonesia. (2005). "Pemberian atau Penolakan Persetujuan Pemanggilan Notaris". Renvoi.

Regulation:

[1] Herzien Inlandsch Reglement (HIR)

[2] Code of Civil law.

[3] Act No. 2 of 2014 concerning Amendments to the Act No. 30 of 2004 concerning Notary Position

[4] Regulation of the Minister of Law and Human Rights Number 7 of 2016 Concerning Notary Honorary Council.

[5] Regulation of the Minister of Law and Human Rights of the Republic of Indonesia.

[6] Regulation of the Minister of Law and Human Rights Number 7 of 2016 concerning the Notary Honorary Council.

[7] Regulation of the Minister of Law and Human Rights of the Republic of Indonesia 
[8] Number M.02.Pr.08.10 of 2004 concerning Procedures for Appointment of Members, Dismissal of Members, Organizational Structure, Work Procedures, and Procedures for Examination of the Notary Supervisory Council

[9] Decree of the Minister of Law and Human Rights of the Republic of Indonesia Number M.39-PW.07.10 of 2004.

[10] Articles of Association, Results of the Extraordinary Congress of the Indonesian Notary Association, Bandung January 27, 2005. 